\title{
Legal Protection for Goodwill Customers in The Purchase of Mortgage Guarantee
}

\author{
Parmo \\ \{parmo_fajri@yahoo.co.id\} \\ Doctor of Law, Universitas Jayabaya, Jakarta, Indonesia
}

\begin{abstract}
Irregularities have been found in the sale and purchase processes, especially among good-faith buyers in the purchase of collateral objects. Disputes and claims over collateral objects purchased by parties third in the District Court often occur. This descriptive legal research was carried out to obtain relevant data to the research problem. Secondary data consisting of primary legal materials, secondary legal materials and tertiary legal materials were regarded. It is concluded that if done based on the procedure, the purchase of collateral objects by good faith buyers is valid, and the agreement cannot be withdrawn other than by an agreement between the two parties or for reasons determined by law. The board of judge tends to perceive the auction buyers as good faith buyers without further examining the legality of the object for they believe any objects sold in an auction is legal as the auction is carried out by a trustworthy institution. Therefore, good faith buyers will obtain legal protection despite the objects are handed out by unauthorized party.
\end{abstract}

Keywords: Legal Protection, Good Faith Buyers, Collateral Objects

\section{Introduction}

Four elements must be fulfilled classically to be considered constitutional law, or rechtstaat in civil law tradition, or the rule of law in common law tradition. The elements are human rights, separation or division of power, government based on regulations, and administrative justice in disputes [1]. The mandate of Article 1 paragraph (3) and Article 23A of the 1945 Constitution of the Republic of Indonesia in several tax laws and other levies that are coercive has not been congruent with three legal values, which according to Gustav Radbruch, consisted of legal certainty, public benefit, and justice. In reality, the factual condition shows that there are still many disputes over taxes, customs and excise, and local- taxes and levies that the tax courts in Indonesia must emphasize. Table 1 summarizes the number of disputes by appeal or defendant during 2014-2020 with 86,349 dispute files, while Table 2 summarizes the settlement of 72,314 tax disputes in 2014-2020 [2].

Commerce law has shown legal deviations, especially for goodwill or good-faith buyers on the purchase of mortgage objects [3]. Many cannot directly enjoy them, given many civil disputes over claims for mortgage objects purchased by third parties from the District Court. Legal protection is a consequence of the so-called rechtstaat based on Article 1 paragraph (3) of the 1945 Constitution of Indonesia (Undang-undang Dasar-UUD 1945) [4]. One of the obligations of the state is to prepare legal instruments for their citizen. These consequences are part of the policy function of state life. The establishment of a statutory mechanism is a continuation of the written and basic unwritten law through investigating the articles, its 
application and spiritual atmosphere, the formulation of the statutory text, the atmosphere in which the statutory text is created, and information related to the process of its formation [5]. All of them is related to the arrangements in the constitution regarding state organizations. Circumstances and time affect several stages of implementing the provisions regarding state organizations [6].

In judicial practice, it seems that goodwill buyers are under the impression of having legal protection. However, the prevailing laws and regulations do not indicate who can be considered as that person. Article 531 of the Civil Code only states that bezit is considered a goodwill gesture if the holder of the position in power acquires the property rights where the person is unbeknownst to any defects or deficiencies. Decisions on civil disputes related to the issue concerning this type of buyer pose a legal dilemma. It places two innocent parties (the original rights holder and the goodwill buyer) asking who should be considered truthful and which party is entitled to legal protection: 1) the holder of the right to the original land; or 2) a goodwill buyer.

Furthermore, Article 1338 paragraph (3) of the Civil Code only states that the agreement must be based on a gesture of goodwill but also does not specify further who can qualify as such a person. This is because goodwill is a value difficult to develop in concrete norms and clear legal explanations. An institution guaranteeing rights and land or land and buildings called mortgage rights is arranged in Article 51 of Law Number 5 of 1960 concerning Basic Agrarian Principles (Undang-Undang Pokok Agraria-UUPA). It then is followed by the issuance of Law Number 4 of 1996 concerning Mortgage on Land and Objects Related to Land (Undang-undang Hak Tanggungan-UUHT).

The execution of the mortgage guarantee is the last step taken by the creditor if the debtor as the provider of the mortgage is in default [7]. The execution is regulated in the UUHT by regulating various execution models so that the relevant parties can choose the execution as they wish. Essentially, the execution of Mortgage Rights can manifest in various ways. Based on Article 20 of the UUHT, if the debtor breaches the contract, the execution of the mortgage will take effect immediately employing.

The auction sale of mortgage objects to determine the next authorized holder is mentioned in Article 6 of the UUHT. Sale through public auction is based on the executorial title that is contained in the mortgage certificate as referred to in Article 14 paragraph (2). It should be following the procedures specified in the legislation for repayment of the dependent's receivables with the right to take precedence over other creditors. The sale of rights of mortgage objects is to facilitate the execution of the creditor who is the rights holder. Should the debtor breach the promise as specified in Article 6 of UUHT, the provisions in Article 6 of the UUHT give the first creditor the right to sell on its authority through a public auction and acquire the revenue from it to compensate the debtor breach of contract.

This study considers that the nature of a positive norm eventually has a binding power when it is adjacent with the power of the authority that establishes it as law in the first place, which in this case, the state. Concerning the thought of legal positivism, the state's role is detailed in Theory of Social Contract by John Locke in his book Two Treatises of Government. John Locke took a different position from Thomas Hobbes' Theory of Social Contract. According to John Locke, human beings are intrinsically malicious. In this case, the state becomes the necessary element to ensure the whole society's security meticulously. The main function of the government is to protect private property rights [8]. The interests of third parties with their goodwill who obtain property rights from instruments of parate executie or public auctions should be a legal consideration when devising legal protection for their own sake. 


\section{Research Methods}

This method of this research is a normative method. Legal research is a study that studies the discipline of law, both in theory and practice. Peter Mahmud Marzuki explained that research is a process to find the rule of law, legal principles, and legal doctrines to answer the legal issues that arise [9].

\section{Results and Discussion}

The customer is considered having goodwill if it has carefully examined the material facts (physical data) and the validity of the transfer of rights (juridical data) on the land they are about to purchase, before, and during the process of transferring land rights. If they have completed the knowledge of defects during the process yet proceed to transact, they cannot be considered goodwill. The goodwill customer needs to understand their obligations by applying the precautionary principle to be considered for legal protection. That is, they should perform a thorough examination of material facts before and during the sale and purchase. According to Article 1338 paragraph (3) of the Civil Code, goodwill in a transaction is the supreme court's consideration at the Plenary Meeting of the Civil Chamber in 2014.

According to the laws and regulations, the customer's obligation with goodwill in a transaction agreement lies in Article 1513 and Article 1514 of the Civil Code. However, it merely states their obligation in the transaction and not regulations on the examination procedure. The existing rules emphasize the transparency and candor of the seller during the transaction of specific goods or objects (Article 1473 of the Civil Code). This article suggests that the broker provides information to the customer about the goods or objects in question. According to emerging opinion in most literature, the assumptions from legislators and the validity of transaction can be confirmed by the role of a notary (Pejabat Pembuat Akta TanahPPAT) and the fulfilment of the required land registration.

Regarding legal protection for goodwill customers with good intentions, Article 1977 paragraph (1) of the Civil Code essentially states that the customer interested in purchasing movable objects with goodwill is eligible to be protected. Article 1977 paragraph (1) of the Civil Code states that "Concerning movable assets which do not comprise interest or debts payable to bearer, the possession of such constitutes absolute ownership."

Furthermore, concerning the arrangement, the Civil Code does not regulate the case of immovable objects. As for this matter, according to Subekti's view, the provisions of Article 1977 paragraph (1) apply to all kinds of goods. Immovable goods need special provisions only stating that if an agreement is made before an official, the parties can be considered in goodwill.

Concerning the disputed mortgage objects that have been transferred to third parties, based on legal rights through the execution of the decision (uitvoerbaar bij voorraad), if the defendant wants the object to be restored to them in a physical form or any kind, they must proceed a civil lawsuit process to the court. The recovery process for such a third party as the winner of the auction lies in Supreme Court Decision Number 323K/Sip/1968. It states that the customer in the executive auction must be protected when there has been an execution bij voorraad, while the relevant court decision is later cancelled. The restorative way can be done by launching a lawsuit to re-obtain the mortgage objects submitted by the executant when applying for an executive request. 
Theoretically, goodwill customers will be protected based on their good intention enshrined in the Civil Code mentioned above. As stated in Article 584 of the Civil Code, goodwill is valid when the property rights are obtained through the transfer of rights, and such rights cannot be separated from the existence of contract law in Article 1338 of the Civil Code paragraph (3) of the Civil Code. It states that an agreement must contain goodwill. This article aims to prevent inappropriate and unlawful acts. The formulation of Article 1338 paragraph (3) of the Civil Code indicates that essentially goodwill alone is not sufficient for the validity of a contract as stated in Article 1320 of the Civil Code. The goodwill is only required to implement an agreement and not understood in a broader objective sense, such as making a contract.

Assessing what constitutes goodwill is achieving a breakthrough in court decisions. Customers are strongly discouraged from being indifferent to the property condition. Rather, they need to perform a thorough inspection upon transaction. The lesson from the decisions above is that legal protection is given only to prudent customers through physical and jurisprudential examination, not to those indifferent to the defects in the transfer of land rights. The development of jurisprudence regarding customers' good faith by adopting the principle of due diligence should be adopted by the judges as a kind of rule of thumb when dealing with similar cases.

The auction winner is entitled to legal protection and legal certainty over the court's decision to cancel the auction result. The way is by asking for compensation to the creditor/auctioneer/holder of the first mortgage through a refund claim that entails the money to purchase the objects, including costs that have been incurred and submitted separately to the authorized agency. The author offers a model of legal protection that can create legal certainty for goodwill customers so that they cannot be made as defendants if there is no evidence regarding a good and correct auction process. Customers can continue to use the precautionary principle in transactions, especially the purchase of mortgage objects. The auction winner claims no responsibility for the losses or deviations that occur as long as they are caused by the creditor and the Auction Service Office.

\section{Conclusion}

The study concludes that the implementation of goodwill among the customers when purchasing the rights of mortgage objects is valid if all agreements are made under the existing law. The agreements mentioned cannot be forfeited unless all parties consented to for reasons determined by the law. For protecting buyers with goodwill as the winners of the auction of disputed rights of mortgage objects, most judges should regard them as such without further assessment of the object's legal status. The judges consider that trustworthy institutions have authorized transactions through auctions, and thus, the goodwill customers in their efforts to obtain property rights will still be protected by law even despite the objects in question are submitted by unauthorized parties.

\section{References}

[1] Atikah, Ika, 'The Urgency Of Mortgage Agreement As An Effort To Realize The Trust By Bank As Creditor', Jurnal Hukum Dan Peradilan, 10.1 (2021) < Https://doi.org/10.25216/jhp.10.1.2021.3163> 
[2] Malekovic, Ninoslav, Lazaros Goutas, Juliana Sutanto, And Dennis Galletta, 'Regret Under Different Auction Designs: The Case Of English And Dutch Auctions', Electronic Markets, 30.1 (2020) <Https://doi.org/10.1007/s12525-019-00355-w>

[3] Marzuki, Peter Mahmud, Penelitian Hukum (Jakarta: Kencana Prenada Media Group, 2011)

[4] Putra, Zaldi Pratama Bagus, 'The Basics Of Good Faith And Good Intention In Land Purchase System In Indonesia', Journal Of Law And Legal Reform, 1.4 (2020) <Https://doi.org/10.15294/jllr.v1i4.39782>

[5] Setiyawan, Wahyu Mukti Beny, And Fitriya Desi Wulandari, 'Law Politic Of Administrative Court Judicature In Indoneesia', International Journal Of Law Reconstruction, 3.1 (2019) <Https://doi.org/10.26532/ijlr.v3i1.4365>

[6] Shubhan, M. Hadi, 'The Utilization Of Unwritten Laws In Bankruptcy Disputes', Jurnal Rechts Vinding: Media Pembinaan Hukum Nasional, $8.1 \quad$ (2019) <Https://doi.org/10.33331/rechtsvinding.v8i1.299>

[7] Tibaka, Leli, And Rosdian Rosdian, 'The Protection Of Human Rights In Indonesian Constitutional Law After The Amendment Of The 1945 Constitution Of The Republic Of Indonesia', Fiat Justisia:Jurnal Ilmu Hukum, 11.3 (2018) <Https://doi.org/10.25041/fiatjustisia.v11no3.1141>

[8] Waddell, Sarah, 'Property Rights For Natural Resources Management In Indonesia: Have They Been Ruled Unconstitutional?', Indonesia Law Review, 2.2 (2012) <Https://doi.org/10.15742/ilrev.v2n2.17> 